\title{
P2X7 receptor orchestrates multiple signalling pathways triggering inflammation, autophagy and metabolic/trophic responses.
}

Running title: P2X7-activated Intracellular Pathways

\author{
Authors: Elisa Orioli*, Elena De Marchi*, Anna Lisa Giuliani*, Elena Adinolfi*§
}

\begin{abstract}
Affiliations:
*Department of Morphology, Surgery and Experimental Medicine, Section of Experimental Pathology, Oncology and Biology, University of Ferrara, Ferrara, Italy

§Corresponding author: Department of Morphology, Surgery and Experimental Medicine, Section of Experimental Pathology, Oncology and Biology, University of Ferrara, Via Luigi Borsari, 46, 44121, Ferrara, Italy; Tel: +39 (0)532 455445; Fax: +39 (0)532 455351: Email: elena.adinolfi@unife.it
\end{abstract}

\begin{abstract}
P2X7 receptor is an ion channel activated by extracellular adenosine trisphosphate (eATP) that attracted increasing attention for its role in immune reactions, neurobiology and oncology. As receptor for an extracellular ligand, P2X7 activates a series of intracellular signalling pathways mainly via alterations of the ion permeability, but also through formation of a large unselective pore and direct interaction with other proteins. Here we wish to give an overview on the main biochemical paths initiated by P2X7 activation by revising recent and established literature on P2X7-triggered signalling cascades leading to cell death, inflammatory and immune response activation, proliferation and metabolism modulation. We will focus on the well-known P2X7 inflammasome/NF-kB and pro-apoptotic networks but also cover P2X7-activated emerging autophagic, pyroptotic and proliferative-oncogenic pathways, like beclin-1/LC3-II, caspase-11, Akt and VEGF axes.
\end{abstract}

Keywords: P2X7, ATP, autophagy, pyroptosis, IL-1ß, NLRP3, Akt, VEGF

\section{Introduction}

P2X7 is a cation channel that, upon engagement by its natural ligand extracellular ATP (eATP), mediates cellular influx of sodium and calcium and efflux of potassium [1]. Moreover, thanks to the presence of its long intracellular tail and following exposure to high $(\mathrm{mM})$ agonist concentrations, P2X7 activates the opening of an unselective pore permeable to solutes in the range of hundreds of Daltons [1-3]. This last feature has been associated to the absence of long-term desensitization and receptor activated cytotoxicity [1]. The human p2rx7 gene is located at chromosome 12 (12q24.31) 
at $130 \mathrm{~kb}$ from its homologous p2rx4 9826911 [4] and its transcription initiation site corresponds to adenine - 91 [5]. The originally cloned rat, human and mouse P2X7 genes comprise 13 exons $[1,4,6]$, nevertheless, different splice variants have been identified including extra exons coding for both longer and shorter proteins [7-10]. Most of the P2X7 splice variants truncated for the $\mathrm{C}$ terminal tail were either non-functional or showed limited agonist response and, with the exception of the human $\mathrm{P} 2 \mathrm{X} 7 \mathrm{~B}$ isoform, acted as dominant negative regulators of the full-length receptor. Conversely, the human P2X7B variant, which is a functional ion channel but cannot form the large conductance pore, attracted attention for its ability to positively modulate P2X7 activities, growth promotion included [11, 12]. More than 1500 human P2X7 single nucleotide polymorphisms (SNPs) were identified, among which, a small number related to receptor's activity including 10 loss and 3 gain of function variants. P2X7 SNPs have been the focus of numerous studies trying to exploit them as biomarkers in pathologies as different as infectious diseases, oncological conditions, metal illnesses and many others (reviewed in [13-15]).

Insights on the secondary and tertiary structure of $\mathrm{P} 2 \mathrm{X} 7$ receptor came from the publication of the crystallographic data of the truncated zebra fish P2X4 followed by those of the human P2X3 and the truncated panda P2X7 receptor [16-19]. These studies allowed for prediction of a common P2X family trimeric organization where each of the three receptor's subunit includes a large extracellular loop, responsible for agonists and antagonists binding, two short transmembrane domains, $\mathrm{N}$ and $\mathrm{C}$ termini, variable in length among receptor subtypes $[14,20]$. Due to the similarity between $\mathrm{P} 2 \mathrm{X}$ monomer and a jumping dolphin, the receptor subunits domains have been named according to the body parts of this animal: the extracellular region being composed by the head, the body, the dorsal fin and the flippers, while the transmembrane helices include the tail and the fluke. Beta-sheets, organized in a $\beta$ sandwich structure, form the body region responsible for the interactions among the three subunits, which form a P2X channel [4, 17, 20]. The P2X7 subunits have the longest $\mathrm{C}$ terminal domain of the $\mathrm{P} 2 \mathrm{X}$ family, making $\mathrm{P} 2 \mathrm{X} 7$ the highest molecular weight $\mathrm{P} 2 \mathrm{X}$ protein accounting for total 595 residues. No structural information is currently available on P2X7 C-terminal region although, nevertheless, based on its sequence it was possible to predict putative binding sites, including one for lipopolysaccharide [21]. Contemporarily, different proteins interacting with P2X7 C-terminal tail were identified either by immunoprecipitation [22-25] or with a yeast two-hybrid strategy [26], including transmembrane, intracellular and heat shock proteins (HSP), cytoskeletal elements and kinases, and the P2X4 receptor. Among these proteins, pannexin-1 plasma membrane hemichannels have been claimed to mediate P2X7-dependent pore opening, IL-1 $\beta$ and ATP release [27, 28]. Many other P2X7 interactors have been identified that are listed and classified in the P2X7 interactome database (http://www.p2x7.co.uk/).

P2X7 ligands including agonists, antagonists and allosteric modulators are either present in nature or were synthetically developed $[14,29,30]$. The P2X7 receptor shows low affinity (i.e. in the mM range) for eATP, while the best known, albeit not completely selective, synthetic agonist is 2'(3')-O-(4-Benzoylbenzoyl) adenosine-5'-triphosphate (Bz-ATP). Other naturally occurring molecules have been attributed a role as P2X7 agonists and positive allosteric modulators including the cathelicidin derived peptide LL-37 [31, 32] and Alzheimer's $\beta$ amyloid 19299738 [33]. Several inhibitors, antagonists or negative allosteric modulators have been developed, some of them administered to patients with a good safety profile [34-36]. The classically used blockers include oxidized-ATP (oATP), brilliant blue G and KN62, which have been recently substituted in in vitro and in vivo studies by more potent and selective antagonists/allosteric modulators, such as AZ10606120, A740003 and its derivative A438079 [14, 37-39]. Further P2X7 positive allosteric modulators, which have been shown to increase P2X7-dependent membrane permeability to large solutes, include drugs, antibiotics and plant derived products, such as tenidap [40], polymixin B 15383600 [41] and ginsenosides [42]. 
P2X7-triggered intracellular signalling was attributed not only to ion fluxes and interacting proteins but also to activation of downstream proteases, kinases and nuclear factors. The biophysical and structural properties of P2X7 and its role as possible therapeutic target in inflammatory disorders and cancer have been recently reviewed [14, 43-47]. Here we wish to give an overview of the main signalling pathways activated by $\mathrm{P} 2 \mathrm{X} 7$ receptor, due to its channel-pore activity or via interacting proteins. We describe the sequence of intracellular events initiated by P2X7 and leading to cell death, autophagy and activation of inflammatory, metabolic and proliferative pathways.

\section{P2X7 receptor activates death pathways leading to apoptosis, autophagy and pyroptosis}

$\mathrm{P} 2 \mathrm{X} 7$ is a molecule able to induce cell death via cell-specific downstream signalling events. Cytotoxic properties are mainly due to its ability to form membrane pores permeable to large molecular weight molecules [48-50]. P2X7 proapoptotic/necrotic activities have been extensively appraised elsewhere [51, 52]. Here we will briefly cover the most salient mechanisms relating P2X7 to apoptotic cell death, besides to emerging evidence on autophagy and pyroptosis.

Among apoptotic-related alterations $\mathrm{P} 2 \mathrm{X} 7$ pore opening associates with cell morphological changes like cell blebbing and shrinkage, nuclear fragmentation and chromatin condensation [53-56] [Fig. 1]. Depending upon the cleaved caspase, apoptosis can be initiated via the extrinsic (caspase-8) or the intrinsic (caspase-9) pathway, both triggered by P2X7 [5659]. Moreover, $\mathrm{P} 2 \mathrm{X} 7$ is known to cause mitochondrial potential collapse and fragmentation followed by cytochrome $\mathrm{c}$ release into the cytosol and ROS production [58, 60, 61]. Interestingly, this last mechanism is reversible upon brief (5-10 minutes) receptor activation. On the other hand, prolonged P2X7 opening triggers cell death via ROCK-1 [58]. Accordingly, the notion that $\mathrm{P} 2 \mathrm{X} 7$ activation can be uncoupled from apoptosis and cytotoxicity has been confirmed by increasing number of studies including those associating P2X7-dependent pore formation and autophagy [2, 62-65].

Autophagy is a self-degradative process indispensable for the equilibrium of energy sources and removal of misfolded proteins or damaged organelles, involved in several pathological conditions [66] [Fig. 1]. A central player in autophagy is the autophagosome that mediates lysosomal targeting and degradation of intracellular debris. Commonly used markers of autophagy include beclin-1 activation, which triggers autophagosome aggregation, and LC3-II association to the autophagosome. Sun and colleagues proposed P2X7-coupling to autophagy consequent to traumatic brain injury [67]. These authors suggested that oATP administration would prevent brain injury-associated cognitive and memory impairments, by reducing beclin-1 levels, thus implying P2X7 as a positive regulator of the authophagic process [67]. On the same line, Young and colleagues demonstrated that in DMD mdx dystrophic-mice myoblasts, P2X7 triggers an autophagic flux starting with increased LC3-II aggregation, which co-localizes with the regions of membrane permeabilization to the large solute Lucifer yellow, i.e. to the P2X7 pore formation sites. In WT and DMD mdx myoblasts P2X7 activation causes increase of LC3-II that can be actively modulated by both upstream and downstream autophagy inhibitors [62]. Moreover, dystrophic myoblasts showed increased LC3-II levels compared to the WT counterpart. Interestingly, in this model P2X7-dependent autophagy was not mediated by calcium but was subordinated to receptor's interaction with HSP90 [62], previously shown to be part of the P2X7 membrane complex [22, 23]. In dystrophic myoblasts, HSP90 inhibition with geldanamycin caused significantly reduced P2X7 pore formation leading to decreased autophagy [62]. Geldanamycin-dependent reduced P2X7 pore opening seems to be myoblast specific as it was not reproduced neither in macrophages [62] nor in P2X7-transfected HEK293 cells [23, 68]. In this last model, geldanamycin treatment rather caused increased P2X7 activity via reduction of the HSP90 tyrosine phosphorylated form [23]. These, apparently contrasting, data may reflect, at least in part, the cellular context involved and, therefore, could be helpful in 
designing dystrophy targeted P2X7 treatments [23, 62]. These may prove beneficial also in light of recent reports linking P2X7 blockade or ablation to reduction of dystrophic symptoms in $\mathrm{mdx}$ mice [69-71]. Increasing evidence associates autophagy to an efficacious defence against intracellular pathogens such as mycobacteria [72, 73]. P2X7 plays a role also in this phenomenon by favouring the elimination of infected macrophages and mycobacteria via autophagolysosome formation [74]. However, while P2X7 generally increases the first phases of autophagy favouring the formation of autophagosomes, in some models the receptor also leads to lysosomal function impairment thus causing a blockade of the overall autophagic flux [75].

P2X7 also triggers pyroptosis, a form of cell death occurring in immune cells via activation of inflammatory caspases $[76,77]$. This is not surprising since, in monocyte/macrophage cell lineage, both $\mathrm{P} 2 \mathrm{X} 7$ activation and pyroptosis cause blebbing, death, IL-1 $\beta$ and IL-18 secretion [52, 78-81]. Pyroptosis requires two particular stimuli, PAMPs (pathogen associated molecular patterns) and DAMPs (damage associated molecular patterns) [78, 82]. ATP is a recognized DAMP that, through P2X7, in dendritic cells and macrophages, mediates the activation of the main pyroptotic caspase, i.e. caspase-1 [80, 83] [Fig. 1]. As above mentioned caspase-1 is not the only caspase required for the initiation of pyroptosis, as one other member of the inflammatory caspases, including caspase- 11 in mice and caspase- 4 and caspase- 5 in humans are necessary [81]. Yang and colleagues have recently shown that P2X7 and pannexin-1 are required for LPS-mediated pyroptosis involving caspase-11 [76]. In LPS treated bone marrow derived macrophages caspase-11 partially cleaves pannexin-1 causing P2X7 activation via eATP release leading to NLRP3 assembly, caspase-1 activation, IL-1 $\beta$ release, gasdermin D cleavage and pyroptosis [76]. These data are also supported by reduced sensitivity to IL-1 $\beta$-dependent endotoxic shock of P2X7, pannexin-1 or caspase-11 null mice [76].

\section{P2X7-related inflammatory pathways}

Once established that P2X7 sustains the maturation and release of IL-1 $\beta$ via $\mathrm{K}^{+}$efflux [83] it was soon evident that the receptor was involved in the activation of the IL-1 $\beta$ maturation platform: the NLRP3 inflammasome [84] [Fig. 2]. Inflammasomes are high molecular weight protein complexes formed in the cytosolic compartment in response to PAMPs or DAMPs, constituted of a sensor and an adaptor molecule plus caspase-1 [85]. The synthetic process of immature, full length, pro-IL-1 $\beta$ originates from the recognition of invading organisms-derived PAMPs. Once synthesised, pro-IL-1 $\beta$ undergoes a proteolytic cleavage by caspase- 1 to generate a mature active cytokine. The activity of caspase-1, in turn, depends on assembly of the NLRP3 inflammasome, which converts pro-caspase-1 into a functioning enzyme [86-88]. The most common mechanism of inflammasome activation is the change in the microenvironment ionic composition with the decrease in $\mathrm{K}^{+}$concentration [89, 90]. Indeed, in 2008 Rubartelli and colleagues first associated P2X7-dependent $\mathrm{K}^{+}$ efflux with NLRP3 inflammasome activation, demonstrating that different danger signals can induce ATP secretion that, in turn, interacting with P2X7, causes IL-1 $\beta$ and IL-18 maturation [84]. This notion has been confirmed in several following papers (revised in [85]) demonstrating that P2X7 triggers NLRP3 inflammasome aggregation and function in macrophages, dendritic and peripheral blood mononuclear cells, neutrophils, microglia and possibly in astrocytes [9195]. Depending upon cell type, P2X7 inflammasome interaction mediates secretion not only of IL-1 $\beta$ and IL-18 but also of other pro-inflammatory cytokines and alarmins such as IL-6 and IL-1 $\alpha[91,96]$.

Three main mechanisms have been proposed to explain P2X7-dependent trigger of NLRP3 inflammasome: $\mathrm{K}^{+}$efflux, ROS production and via direct interaction. Although the requirement of $\mathrm{K}^{+}$efflux is well established [77, 97, 98], little is 
known about the mechanism by which $\mathrm{K}^{+}$concentration drop is translated into intracellular signals. Recent studies have partially elucidated this question suggesting that NEK7 kinase will sense the ATP-induced $\mathrm{K}^{+}$decrease and bind to NLRP3 inflammasome regulating its function [99, 100]. In addition, Yaron and colleagues have recently suggested that P2X7-dependent $\mathrm{K}^{+}$efflux would be leading mitochondrial ROS generation, via organellar $\mathrm{Ca}^{2+}$ influx, causing inflammasome activation [101]. P2X7-dependent ROS production via NADPH activation is an established data [102104] that has been shown to be dependent upon the MEK-ERK signalling network [104] to cause IL-1 $\beta$ secretion [103, 105, 106] and autophagy activation [107]. P2X7 engagement by ATP also determines uncoupling of the thioredoxin (TRX)/TRX reductase (TRXR) system eliciting ROS-dependent inflammasome recruitment [108]. In this context, the $\mathrm{P} 2 \mathrm{X} 7 / \mathrm{P} 2 \mathrm{X} 4$ complex plays a controversial role as P2X4 has been claimed to both up-modulate and decrease ROS formation and inflammasome activation through interaction with P2X7 [106, 107]. Finally, emerging evidence suggests that P2X7 could directly interact with components of different inflammasomes including NLRP2, ASC and NLRP3 [95, $109,110]$. The presence of P2X7 receptor in the same protein complex with NLRP2 and ASC will explain an unconventional IL-1 $\beta$ maturation in non-immune cells such astrocytes [95]. In a more conventional situation, such as peritoneal macrophages, P2X7-NLRP3 interaction drives NLRP3 association to the interior leaflet of plasma membrane, via discrete $\mathrm{Ca}^{2+}$ concentration increase. Calcium influx also induces the progressive accumulation of $\mathrm{P} 2 \mathrm{X} 7$ at the NLRP3/P2X7 membrane complex, finally resulting in a striking rise of the two proteins in a defined plasmalemmal region [109]. Despite interaction, NLRP3/P2X7 crosstalk is complicated by an inverse correlation of their expression. Indeed, P2X7 null mice express enhanced NLRP3 levels [109] whereas, on the contrary, NLRP3 KO animals over-express P2X7 [110]. Interestingly, this inverse relation was also found in chronic lymphocytic leukemia patients, which while overexpressing P2X7, showed dramatically reduced NLRP3 levels that correlated with increased cell survival/proliferation [110]. Hematologic malignancies are not the only pathologic situation exacerbated or induced by the P2X7inflammasome axis. Indeed, a growing body of literature reports a role for P2X7/NLRP3 and related proteins in several pathological conditions including response to infective agents [111-114], depressive and gestational disorders [115-119], epilepsy [120], fibrosis [121], osteonecrosis [122], liver, kidney and brain injury [123-126].

The relevance of P2X7 is not limited to IL-1 $\beta$ maturation and secretion but also extended to activation of NF-kB, the main nuclear factor responsible for pro-IL-1 $\beta$ synthesis. NF-kB is a transcription factor covering a pivotal role in modulating cytokine expression in response to different stimuli such as TNF- $\alpha$, IL-1 $\beta$ and TLRs agonists, relevant in cell growth and carcinogenesis, too [127-129]. The five members of the mammalian NF-kB family are present in unstimulated cells as homo- or hetero-dimers bound to IkB family proteins [130]. Binding to IkB prevents the NF-kB/IkB complex from translocation to the nucleus, thus maintaining NF-kB inactive. On the contrary, free NF-kB dimers are able to translocate to the nucleus leading to a robust proinflammatory gene expression [131-133]. P2X7 activation by eATP has been included among various stimuli of the NF-kB pathway for a long time [134]. Activated P2X7 was indeed, found to induce NF-kB pathway activation resulting in selective DNA binding of NF-kB subunit p65 in microglia, osteoclasts and osteoblasts [134-136]. A following study suggested P2X7 as responsible for NF-kB activation through the MyD88 pathway [137] since MyD88 silencing almost abolished P2X7-induced NF-kB activation. Co-immunoprecipitation experiments suggested a direct P2X7/MyD88 interaction, which was lost upon P2X7 C-terminal region truncation [137]. Of interest, P2X7 antagonist administration in murine models of inflammatory diseases as colitis and liver fibrosis, resulted in striking reduction of symptoms and NF-kB levels [138, 139]. Moreover, different pro-inflammatory agents were shown to increase P2X7/NF-kB levels $[140,141]$ while anti-inflammatory substances exerted an opposite response 
$[142,143]$. Finally, P2X7-dependent NF-kB activation mediated by the ERK $1 / 2$ and Akt signalling paths has been associated to tumoral response to hypoxia and acquisition of a malignant invasive prone phenotype [144].

P2X7 has been attributed an additional role in the immune response consisting in positive regulation of $\mathrm{T}$ cell proliferation. A seminal study by Baricordi and colleagues demonstrated that ATP via P2X7 increased TCR mediated T lymphocytes proliferation [145]. This hypothesis was confirmed by following studies demonstrating that oATP administration in two preclinical models of transplantation acted as an efficient immune-suppressor by reducing T-cell activation [146, 147]. The mechanism mediating P2X7 dependent T-cell proliferation involves FAK and NFAT activation and leads to IL-2 secretion [148, 149]. P2X7-stimulated NFAT activation is not unexpected as this nuclear factor is calcium/calcineurin sensitive. Indeed, NFAT activation was associated to P2X7-dependent proliferation also in non-lymphocytic cells such as HEK-293, osteoblasts, microglia, osteosarcoma and other tumour cells [11, 12, 37, 150-152]. In microglia, the $\mathrm{P} 2 \mathrm{X} 7 /$ calcineurin/NFAT axis mediates the activation of several pro-inflammatory chemotactic pathways including those leading to production and secretion of CCL3 and CXCL2, IL-6, PGE2, NO and ROS [153-155]. Conversely, P2X7 activation could exert a negative regulation of NFAT signalling in B-lymphocytes. In fact, Pippel and colleagues have recently reported that simultaneous activation of $\mathrm{B}$ cell receptor and $\mathrm{P} 2 \mathrm{X} 7$ causes reduction of NFAT nuclear translocation possibly due to P2X7 dependent membrane depolarization [156].

\section{P2X7 positively regulates the HIF-1 $\alpha$-VEGF axis}

The HIF- $1 \alpha$-VEGF axis pathway bridges inflammation, tissue repair and carcinogenesis. Growing evidence has confirmed a role for P2X7 receptor in VEGF secretion and HIF-1 $\alpha$ /VEGFR2 modulation. In 2010, Hill and colleagues reported P2X7-dependent VEGF release from monocytes suggesting a role for the receptor in the control of angiogenesis and wound repair [157] [Fig. 3]. This assumption was confirmed in in vivo models of pathological neovascularization $[158,159]$, as P2X7 blockers administration in murine models of splanchnic angiogenesis alleviated hyperaemia and mesenteric vascular density by reducing both VEGF and VEGFR2 [158]. Accordingly, in a model of laser induced choroidal neo-vascularization, intraocular A438079 administration significantly reduced VEGF secretion. In the same model, P2X7 null mice showed reduced VEGF levels in the retinal pigment epithelium choroid [159]. Hypoxia, via HIF$1 \alpha$ activation, plays a central role in VEGF secretion induction and the hypoxic microenvironment developing in the core of a growing tumour drives neovascularization via the HIF-1 $\alpha /$ VEGF axis. Activation of these proangiogenic factors is a prerequisite for tumour progression thanks to their ability to ensure oxygen and nutrients through vascularization. Hypoxia, via HIF-1 $\alpha$, also upregulates P2X7 expression [144, 160] and, in turn, P2X7-dependent HIF-1 $\alpha$ activation was shown in both cell cultures and experimental tumours $[39,161]$. Consequently, P2X7-dependent VEGF secretion from cancer cells is a frequent finding [37, 39, 162, 163]. Therefore, it is not surprising that P2X7 enhances tumour vascularization in several experimental models, including colon carcinoma, melanoma and neuroblastoma [37, 39]. On the same line, P2X7-induced vascularization is central in receptor's oncogenic function as the P2X7-conferred growing advantage was reverted by VEGF antagonist, bevacizumab [37]. Accordingly, Solini et al. have recently demonstrated that the association of loss of function SNPs in both VEGFR2 and P2X7 correlates to favourable prognosis in prostate cancer suggesting a worsening in cancer evolution following their hyper-activity [164].

\section{P2X7-dependent metabolic pathways: the PI3K/Akt/GSK3ß axes}


HIF-1 $\alpha$ and VEGF are not the only oncogenic proteins activated by P2X7. Indeed, it is now well accepted that P2X7 tonic stimulation by ATP concentrations unable to cause pore formation, gives to cells a proliferative advantage thus conferring to $\mathrm{P} 2 \mathrm{X} 7$ a bi-functional role in either cell death or growth $[46,165]$. The seminal papers reporting a trophic role for P2X7 came from Baricordi and Di Virgilio's laboratories [145, 166, 167]. Starting from these observations, we firstly investigated the basis of this trophic effect showing a P2X7-dependent enhanced mitochondrial energy state, a better handling of $\mathrm{ER} \mathrm{Ca}^{2+}$ and an important activation of the NFATc1 transcription factor [60,150] [Fig. 3]. On the same line, we also pointed out the importance of $\mathrm{P} 2 \mathrm{X} 7$ as aerobic glycolysis upstream modulator through the observation that P2X7transfected HEK293 cells augment lactate release, overexpress phosphofructokinase, glyceraldehyde 3-phosphate dehydrogenase, pyruvate kinase M2 and dehydrogenase kinase 1 and the glucose transporter Glut1. Consequently, P2X7 expressing cells show larger glycogen stores and present increased phosphorylated Akt and HIF-1 $\alpha$ levels [161]. Therefore, P2X7 seems to favour cell adaptability to adverse conditions through glycolytic enzymes upregulation and intracellular glycogen depots increase [161]. A following study confirmed these results demonstrating that P2X7 upregulates the PI3K/Akt signalling cascade both in tumour cells and in neuroblastoma bearing mice [39] [Fig. 3]. The PI3K signalling network is a recognized oncogenic pathway, which comprises PI3K itself, Akt and GSK3ß. PI3K/Akt signalling increases GSK3 $\beta$ phosphorylation, that is associated with reduced GSK3 $\beta$ activity $[168,169]$. In its un-phosphorylated form, GSK3 $\beta$ mediates proteasome degradation of different oncoproteins, including MYCN, thus behaving as an antioncogene [170]. Using an in vivo/in vitro approach in two different neuroblastoma experimental models, we have demonstrated that P2X7 over-activates PI3K/Akt while driving GSK3 $\beta$ inactivation, finally leading to glycogen accumulation. Moreover, administration of $\mathrm{P} 2 \mathrm{X} 7$ targeting drugs to neuroblastoma bearing mice caused not only significant reduced tumour growth rate but also incremented GSK3 $\beta$ activity provoking an almost complete MYCN lack. Co-administration of PI3K and P2X7 blocking drugs did not cause any additive effect suggesting that P2X7 could be an upstream modulator of PI3K [39]. Noticeably, in neuroblastoma Akt itself can up-modulate P2X7 expression via EGFR and the nuclear factor Sp-1, suggesting that oncogenesis will induce an Akt/P2X7 positive loop [171]. On the same line, P2X7 activation of PI3K/Akt signalling cascade was attributed a role in tumour cell migration, metastatic spreading and epithelial-mesenchymal transition, all features of tumour progression towards malignancy [172-174]. Statins-related reduced cancer risk [175] was also hypothesised to be dependent on P2X7 activity down-modulation and consequent Akt nuclear levels reduction [176-179]. Tumour cells are not the only model in which P2X7-dependedent PI3K and Akt activation has been reported, as it is long known P2X7 activation of this pathway, via calcium influx, also in astrocytes and osteoblasts [180, 181]. 19384592 In astrocytes and cerebellar granule neurons, while, similarly to neuroblastoma cells, P2X7 activates Akt and inhibits GSK3 $\beta$, GSK3 $\beta$ blockade was not a direct consequence of PI3K/Akt activation, rather due to P2X7-mediated calcium influx causing PKC activation Inserire ortega19384592[182, 183]. Thus, the different signalling pathways downstream P2X7 could be differentially connected depending upon cell type and physiopathological condition.

\section{Conclusions}

Since its discovery, P2X7 receptor was identified as key modulator of several pathophysiological processes. This is probably not surprising, considering its widespread cellular expression and ability to sense eATP, one of the most ancient molecules appeared during evolution. Accordingly, the signalling cascades initiated by P2X7, ranging from cell death to proliferation, from immune system activation to vascularization and metabolic reprogramming, depend upon the cell type involved and the eATP concentration. Although the number of proteins claimed to be activated by P2X7 is extended, we 
believe that will be further increasing, thus allowing better elucidation of receptor dependent cellular dynamics and their pathophysiological implications. A further effort in this direction, enabling complete depiction of P2X7 partner proteins and activated pathways, will be also required in view of the possible use of P2X7 targeting drugs in the cure of inflammatory diseases, pain and cancer.

\section{Abbreviations:}

ATP: adenosine triphosphate; BzATP: 2'(3')-O-(4-Benzoylbenzoyl)adenosine-5'-triphosphate; DAMP: damage

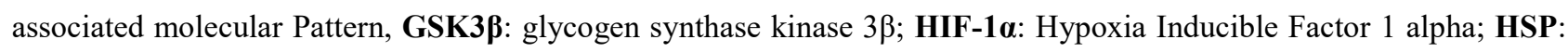
heat shock proteins; NFAT: Nuclear factor of activated T-cells; NF-kB: nuclear factor kB; NLRP: NACHT, LRR and PYD domains-containing protein, PAMP: pathogen associated molecular pattern, PI3K: phosphatidylinositol-trisphosphate kinase 3; ROS: Reactive oxygen species; VEGF: Vascular endothelial growth factor; NEK7: NIMA related kinase 7.

\section{Conflict of Interest}

The authors confirm that this article content has no conflict of interest.

\section{Acknowledgements}

EA, EO, EDM are supported by grants from the Italian Association for Cancer Research (AIRC IG16812) and the Region Emilia Romagna (Bando Alessandro Liberati), PI: EA. EA and ALG also thanks the University of Ferrara for continuous financial support. The authors are grateful to Doctor Carmen Fotino for critical reading of the manuscript.

\section{References}

[1] Surprenant, A.; Rassendren, F.; Kawashima, E.; North, R.A.; Buell, G., The cytolytic P2Z receptor for extracellular ATP identified as a P2X receptor (P2X7). Science, 1996, 272, (5262), 735-738.

[2] Falzoni, S.; Munerati, M.; Ferrari, D.; Spisani, S.; Moretti, S.; Di Virgilio, F., The purinergic P2Z receptor of human macrophage cells. Characterization and possible physiological role. J Clin Invest, 1995, 95, (3), $1207-1216$.

[3] Virginio, C.; MacKenzie, A.; Rassendren, F.A.; North, R.A.; Surprenant, A., Pore dilation of neuronal P2X receptor channels. Nat Neurosci, 1999, 2, (4), 315-321.

[4] Buell, G.N.; Talabot, F.; Gos, A.; Lorenz, J.; Lai, E.; Morris, M.A.; Antonarakis, S.E., Gene structure and chromosomal localization of the human P2X7 receptor. Receptors Channels, 1998, 5, (6), 347-354.

[5] Zhou, L.; Luo, L.; Qi, X.; Li, X.; Gorodeski, G.I., Regulation of P2X(7) gene transcription. Purinergic Signal, 2009, 5, (3), 409-426.

[6] Chessell, I.P.; Simon, J.; Hibell, A.D.; Michel, A.D.; Barnard, E.A.; Humphrey, P.P., Cloning and functional characterisation of the mouse $\mathrm{P} 2 \mathrm{X} 7$ receptor. FEBS Lett, 1998, 439, (1-2), 26-30.

[7] Cheewatrakoolpong, B.; Gilchrest, H.; Anthes, J.C.; Greenfeder, S., Identification and characterization of splice variants of the human P2X7 ATP channel. Biochem Biophys Res Commun, 2005, 332, (1), 17-27. 
[8] Feng, Y.H.; Li, X.; Wang, L.; Zhou, L.; Gorodeski, G.I., A truncated P2X7 receptor variant (P2X7-j) endogenously expressed in cervical cancer cells antagonizes the full-length $\mathrm{P} 2 \mathrm{X} 7$ receptor through heterooligomerization. J Biol Chem, 2006, 281, (25), 17228-17237.

[9] Masin, M.; Young, C.; Lim, K.; Barnes, S.J.; Xu, X.J.; Marschall, V.; Brutkowski, W.; Mooney, E.R.; Gorecki, D.C.; Murrell-Lagnado, R., Expression, assembly and function of novel C-terminal truncated variants of the mouse P2X7 receptor: re-evaluation of P2X7 knockouts. Br J Pharmacol, 2012, 165, (4), 978-993.

[10] Nicke, A.; Kuan, Y.H.; Masin, M.; Rettinger, J.; Marquez-Klaka, B.; Bender, O.; Gorecki, D.C.; MurrellLagnado, R.D.; Soto, F., A functional P2X7 splice variant with an alternative transmembrane domain 1 escapes gene inactivation in P2X7 knock-out mice. J Biol Chem, 2009, 284, (38), 25813-25822.

[11] Adinolfi, E.; Cirillo, M.; Woltersdorf, R.; Falzoni, S.; Chiozzi, P.; Pellegatti, P.; Callegari, M.G.; Sandona, D.; Markwardt, F.; Schmalzing, G.; Di Virgilio, F., Trophic activity of a naturally occurring truncated isoform of the P2X7 receptor. FASEB J, 2010, 24, (9), 3393-3404.

[12] Giuliani, A.L.; Colognesi, D.; Ricco, T.; Roncato, C.; Capece, M.; Amoroso, F.; Wang, Q.G.; De Marchi, E.; Gartland, A.; Di Virgilio, F.; Adinolfi, E., Trophic activity of human P2X7 receptor isoforms A and B in osteosarcoma. PLoS One, 2014, 9, (9), e107224.

[13] Sluyter, R.; Stokes, L., Significance of P2X7 receptor variants to human health and disease. Recent Pat DNA Gene Seq, 2011, 5, (1), 41-54.

[14] De Marchi, E.; Orioli, E.; Dal Ben, D.; Adinolfi, E., P2X7 Receptor as a Therapeutic Target. Adv Protein Chem Struct Biol, 2016, 104, 39-79.

[15] Miller, C.M.; Boulter, N.R.; Fuller, S.J.; Zakrzewski, A.M.; Lees, M.P.; Saunders, B.M.; Wiley, J.S.; Smith, N.C., The role of the P2X(7) receptor in infectious diseases. PLoS Pathog, 2011, 7, (11), e1002212.

[16] Kawate, T.; Michel, J.C.; Birdsong, W.T.; Gouaux, E., Crystal structure of the ATP-gated P2X(4) ion channel in the closed state. Nature, 2009, 460, (7255), 592-598.

[17] Hattori, M.; Gouaux, E., Molecular mechanism of ATP binding and ion channel activation in P2X receptors. Nature, 2012, 485, (7397), 207-212.

[18] Mansoor, S.E.; Lu, W.; Oosterheert, W.; Shekhar, M.; Tajkhorshid, E.; Gouaux, E., X-ray structures define human P2X3 receptor gating cycle and antagonist action. Nature, 2016, 538, (7623), 66-71.

[19] Karasawa, A.; Kawate, T., Structural basis for subtype-specific inhibition of the P2X7 receptor. Elife, $2016,5$.

[20] Grimes, L.; Young, M.T., Purinergic P2X receptors: structural and functional features depicted by X-ray and molecular modelling studies. Curr Med Chem, 2015, 22, (7), 783-798.

[21] Denlinger, L.C.; Fisette, P.L.; Sommer, J.A.; Watters, J.J.; Prabhu, U.; Dubyak, G.R.; Proctor, R.A.; Bertics, P.J., Cutting edge: the nucleotide receptor P2X7 contains multiple protein- and lipid-interaction motifs including a potential binding site for bacterial lipopolysaccharide. J Immunol, 2001, 167, (4), 1871-1876.

[22] Kim, M.; Jiang, L.H.; Wilson, H.L.; North, R.A.; Surprenant, A., Proteomic and functional evidence for a P2X7 receptor signalling complex. EMBO J, 2001, 20, (22), 6347-6358.

[23] Adinolfi, E.; Kim, M.; Young, M.T.; Di Virgilio, F.; Surprenant, A., Tyrosine phosphorylation of HSP90 within the P2X7 receptor complex negatively regulates P2X7 receptors. J Biol Chem, 2003, 278, (39), 37344-37351.

[24] Pelegrin, P.; Surprenant, A., Pannexin-1 mediates large pore formation and interleukin-1beta release by the ATPgated $\mathrm{P} 2 \mathrm{X} 7$ receptor. EMBO J, 2006, 25, (21), 5071-5082.

[25] Guo, C.; Masin, M.; Qureshi, O.S.; Murrell-Lagnado, R.D., Evidence for functional P2X4/P2X7 heteromeric receptors. Mol Pharmacol, 2007, 72, (6), 1447-1456. 
[26] Wilson, H.L.; Wilson, S.A.; Surprenant, A.; North, R.A., Epithelial membrane proteins induce membrane blebbing and interact with the P2X7 receptor C terminus. J Biol Chem, 2002, 277, (37), 34017-34023.

[27] Pelegrin, P.; Surprenant, A., Pannexin-1 couples to maitotoxin- and nigericin-induced interleukin-1beta release through a dye uptake-independent pathway. J Biol Chem, 2007, 282, (4), 2386-2394.

[28] Baroja-Mazo, A.; Barbera-Cremades, M.; Pelegrin, P., The participation of plasma membrane hemichannels to purinergic signaling. Biochim Biophys Acta, 2013, 1828, (1), 79-93.

[29] Lambertucci, C.; Dal Ben, D.; Buccioni, M.; Marucci, G.; Thomas, A.; Volpini, R., Medicinal chemistry of P2X receptors: agonists and orthosteric antagonists. Curr Med Chem, 2015, 22, (7), 915-928.

[30] Jacobson, K.A.; Muller, C.E., Medicinal chemistry of adenosine, P2Y and P2X receptors. Neuropharmacology, 2016, 104, 31-49.

[31] Elssner, A.; Duncan, M.; Gavrilin, M.; Wewers, M.D., A novel P2X7 receptor activator, the human cathelicidinderived peptide LL37, induces IL-1 beta processing and release. J Immunol, 2004, 172, (8), 4987-4994.

[32] Tomasinsig, L.; Pizzirani, C.; Skerlavaj, B.; Pellegatti, P.; Gulinelli, S.; Tossi, A.; Di Virgilio, F.; Zanetti, M., The human cathelicidin LL-37 modulates the activities of the P2X7 receptor in a structure-dependent manner. $J$ Biol Chem, 2008, 283, (45), 30471-30481.

[33] Sanz, J.M.; Chiozzi, P.; Ferrari, D.; Colaianna, M.; Idzko, M.; Falzoni, S.; Fellin, R.; Trabace, L.; Di Virgilio, F., Activation of microglia by amyloid \{beta\} requires P2X7 receptor expression. J Immunol, 2009, 182, (7), 4378-4385. [34] Stock, T.C.; Bloom, B.J.; Wei, N.; Ishaq, S.; Park, W.; Wang, X.; Gupta, P.; Mebus, C.A., Efficacy and safety of CE-224,535, an antagonist of P2X7 receptor, in treatment of patients with rheumatoid arthritis inadequately controlled by methotrexate. J Rheumatol, 2012, 39, (4), 720-727.

[35] Ali, Z.; Laurijssens, B.; Ostenfeld, T.; McHugh, S.; Stylianou, A.; Scott-Stevens, P.; Hosking, L.; Dewit, O.; Richardson, J.C.; Chen, C., Pharmacokinetic and pharmacodynamic profiling of a P2X7 receptor allosteric modulator GSK1482160 in healthy human subjects. Br J Clin Pharmacol, 2013, 75, (1), 197-207.

[36] Eser, A.; Colombel, J.F.; Rutgeerts, P.; Vermeire, S.; Vogelsang, H.; Braddock, M.; Persson, T.; Reinisch, W., Safety and Efficacy of an Oral Inhibitor of the Purinergic Receptor P2X7 in Adult Patients with Moderately to Severely Active Crohn's Disease: A Randomized Placebo-controlled, Double-blind, Phase IIa Study. Inflamm Bowel Dis, 2015, $21,(10), 2247-2253$.

[37] Adinolfi, E.; Raffaghello, L.; Giuliani, A.L.; Cavazzini, L.; Capece, M.; Chiozzi, P.; Bianchi, G.; Kroemer, G.; Pistoia, V.; Di Virgilio, F., Expression of P2X7 receptor increases in vivo tumor growth. Cancer Res, 2012, 72, (12), 2957-2969.

[38] Adinolfi, E.; Capece, M.; Franceschini, A.; Falzoni, S.; Giuliani, A.L.; Rotondo, A.; Sarti, A.C.; Bonora, M.; Syberg, S.; Corigliano, D.; Pinton, P.; Jorgensen, N.R.; Abelli, L.; Emionite, L.; Raffaghello, L.; Pistoia, V.; Di Virgilio, F., Accelerated tumor progression in mice lacking the ATP receptor P2X7. Cancer Res, 2015, 75, (4), 635-644.

[39] Amoroso, F.; Capece, M.; Rotondo, A.; Cangelosi, D.; Ferracin, M.; Franceschini, A.; Raffaghello, L.; Pistoia, V.; Varesio, L.; Adinolfi, E., The P2X7 receptor is a key modulator of the PI3K/GSK3beta/VEGF signaling network: evidence in experimental neuroblastoma. Oncogene, 2015, 34, (41), 5240-5251.

[40] Sanz, J.M.; Chiozzi, P.; Di Virgilio, F., Tenidap enhances P2Z/P2X7 receptor signalling in macrophages. Eur J Pharmacol, 1998, 355, (2-3), 235-244.

[41] Ferrari, D.; Pizzirani, C.; Adinolfi, E.; Forchap, S.; Sitta, B.; Turchet, L.; Falzoni, S.; Minelli, M.; Baricordi, R.; Di Virgilio, F., The antibiotic polymyxin B modulates P2X7 receptor function. J Immunol, 2004, 173, (7), 4652-4660. 
[42] Helliwell, R.M.; ShioukHuey, C.O.; Dhuna, K.; Molero, J.C.; Ye, J.M.; Xue, C.C.; Stokes, L., Selected ginsenosides of the protopanaxdiol series are novel positive allosteric modulators of $\mathrm{P} 2 \mathrm{X} 7$ receptors. Br J Pharmacol, 2015, 172, (13), 3326-3340.

[43] North, R.A., P2X receptors. Philos Trans R Soc Lond B Biol Sci, 2016, 371, (1700).

[44] North, R.A.; Jarvis, M.F., P2X receptors as drug targets. Mol Pharmacol, 2013, 83, (4), 759-769.

[45] Di Virgilio, F.; Adinolfi, E., Extracellular purines, purinergic receptors and tumor growth. Oncogene, 2016.

[46] Adinolfi, E.; Capece, M.; Amoroso, F.; De Marchi, E.; Franceschini, A., Emerging roles of P2X receptors in cancer. Curr Med Chem, 2015, 22, (7), 878-890.

[47] Di Virgilio, F., P2X receptors and inflammation. Curr Med Chem, 2015, 22, (7), 866-877.

[48] Steinberg, T.H.; Newman, A.S.; Swanson, J.A.; Silverstein, S.C., ATP4- permeabilizes the plasma membrane of mouse macrophages to fluorescent dyes. J Biol Chem, 1987, 262, (18), 8884-8888.

[49] Di Virgilio, F.; Bronte, V.; Collavo, D.; Zanovello, P., Responses of mouse lymphocytes to extracellular adenosine 5'-triphosphate (ATP). Lymphocytes with cytotoxic activity are resistant to the permeabilizing effects of ATP. J Immunol, 1989, 143, (6), 1955-1960.

[50] Di Virgilio, F., The P2Z purinoceptor: an intriguing role in immunity, inflammation and cell death. Immunol Today, 1995, 16, (11), 524-528.

[51] Di Virgilio, F., Dr. Jekyll/Mr. Hyde: the dual role of extracellular ATP. J Auton Nerv Syst, 2000, 81, (1-3), 5963.

[52] Adinolfi, E.; Pizzirani, C.; Idzko, M.; Panther, E.; Norgauer, J.; Di Virgilio, F.; Ferrari, D., P2X(7) receptor: Death or life? Purinergic Signal, 2005, 1, (3), 219-227.

[53] Zanovello, P.; Bronte, V.; Rosato, A.; Pizzo, P.; Di Virgilio, F., Responses of mouse lymphocytes to extracellular ATP. II. Extracellular ATP causes cell type-dependent lysis and DNA fragmentation. J Immunol, 1990, 145, (5), 15451550 .

[54] Zheng, L.M.; Zychlinsky, A.; Liu, C.C.; Ojcius, D.M.; Young, J.D., Extracellular ATP as a trigger for apoptosis or programmed cell death. J Cell Biol, 1991, 112, (2), 279-288.

[55] MacKenzie, A.; Wilson, H.L.; Kiss-Toth, E.; Dower, S.K.; North, R.A.; Surprenant, A., Rapid secretion of interleukin-1beta by microvesicle shedding. Immunity, 2001, 15, (5), 825-835.

[56] Ferrari, D.; Los, M.; Bauer, M.K.; Vandenabeele, P.; Wesselborg, S.; Schulze-Osthoff, K., P2Z purinoreceptor ligation induces activation of caspases with distinct roles in apoptotic and necrotic alterations of cell death. FEBS Lett, 1999, 447, (1), 71-75.

[57] Aguirre, A.; Shoji, K.F.; Saez, J.C.; Henriquez, M.; Quest, A.F., FasL-triggered death of Jurkat cells requires caspase 8-induced, ATP-dependent cross-talk between Fas and the purinergic receptor P2X(7). J Cell Physiol, 2013, 228, (2), 485-493.

[58] Mackenzie, A.B.; Young, M.T.; Adinolfi, E.; Surprenant, A., Pseudoapoptosis induced by brief activation of ATP-gated P2X7 receptors. J Biol Chem, 2005, 280, (40), 33968-33976.

[59] Wen, L.T.; Caldwell, C.C.; Knowles, A.F., Poly(ADP-ribose) polymerase activation and changes in Bax protein expression associated with extracellular ATP-mediated apoptosis in human embryonic kidney 293-P2X7 cells. Mol Pharmacol, 2003, 63, (3), 706-713.

[60] Adinolfi, E.; Callegari, M.G.; Ferrari, D.; Bolognesi, C.; Minelli, M.; Wieckowski, M.R.; Pinton, P.; Rizzuto, R.; Di Virgilio, F., Basal activation of the P2X7 ATP receptor elevates mitochondrial calcium and potential, increases cellular ATP levels, and promotes serum-independent growth. Mol Biol Cell, 2005, 16, (7), 3260-3272. 
[61] Souza, C.O.; Santoro, G.F.; Figliuolo, V.R.; Nanini, H.F.; de Souza, H.S.; Castelo-Branco, M.T.; Abalo, A.A.; Paiva, M.M.; Coutinho, C.M.; Coutinho-Silva, R., Extracellular ATP induces cell death in human intestinal epithelial cells. Biochim Biophys Acta, 2012, 1820, (12), 1867-1878.

[62] Young, C.N.; Sinadinos, A.; Lefebvre, A.; Chan, P.; Arkle, S.; Vaudry, D.; Gorecki, D.C., A novel mechanism of autophagic cell death in dystrophic muscle regulated by P2RX7 receptor large-pore formation and HSP90. Autophagy, 2015, 11, (1), 113-130.

[63] Raffaghello, L.; Chiozzi, P.; Falzoni, S.; Di Virgilio, F.; Pistoia, V., The P2X7 receptor sustains the growth of human neuroblastoma cells through a substance P-dependent mechanism. Cancer Res, 2006, 66, (2), 907-914.

[64] Bianchi, G.; Vuerich, M.; Pellegatti, P.; Marimpietri, D.; Emionite, L.; Marigo, I.; Bronte, V.; Di Virgilio, F.; Pistoia, V.; Raffaghello, L., ATP/P2X7 axis modulates myeloid-derived suppressor cell functions in neuroblastoma microenvironment. Cell Death Dis, 2014, 5, e1135.

[65] Salvestrini, V.; Orecchioni, S.; Talarico, G.; Reggiani, F.; Mazzetti, C.; Bertolini, F.; Orioli, E.; Adinolfi, E.; Di Virgilio, F.; Pezzi, A.; Cavo, M.; Lemoli, R.M.; Curti, A., Extracellular ATP induces apoptosis through P2X7R activation in acute myeloid leukemia cells but not in normal hematopoietic stem cells. Oncotarget, 2016.

[66] Glick, D.; Barth, S.; Macleod, K.F., Autophagy: cellular and molecular mechanisms. J Pathol, 2010, 221, (1), $3-12$.

[67] Sun, L.; Gao, J.; Zhao, M.; Cui, J.; Li, Y.; Yang, X.; Jing, X.; Wu, Z., A novel cognitive impairment mechanism that astrocytic p-connexin 43 promotes neuronic autophagy via activation of P2X7R and down-regulation of GLT-1 expression in the hippocampus following traumatic brain injury in rats. Behav Brain Res, 2015, 291, 315-324.

[68] Migita, K.; Ozaki, T.; Shimoyama, S.; Yamada, J.; Nikaido, Y.; Furukawa, T.; Shiba, Y.; Egan, T.M.; Ueno, S., HSP90 Regulation of P2X7 Receptor Function Requires an Intact Cytoplasmic C-Terminus. Mol Pharmacol, 2016, 90 , (2), 116-126.

[69] Sinadinos, A.; Young, C.N.; Al-Khalidi, R.; Teti, A.; Kalinski, P.; Mohamad, S.; Floriot, L.; Henry, T.; Tozzi, G.; Jiang, T.; Wurtz, O.; Lefebvre, A.; Shugay, M.; Tong, J.; Vaudry, D.; Arkle, S.; doRego, J.C.; Gorecki, D.C., P2RX7 purinoceptor: a therapeutic target for ameliorating the symptoms of duchenne muscular dystrophy. PLoS Med, 2015, 12, (10), e1001888.

[70] Gazzerro, E.; Baldassari, S.; Assereto, S.; Fruscione, F.; Pistorio, A.; Panicucci, C.; Volpi, S.; Perruzza, L.; Fiorillo, C.; Minetti, C.; Traggiai, E.; Grassi, F.; Bruno, C., Enhancement of Muscle T Regulatory Cells and Improvement of Muscular Dystrophic Process in mdx Mice by Blockade of Extracellular ATP/P2X Axis. Am J Pathol, 2015, 185, (12), 3349-3360.

[71] Mohamad, N.S.; Sinadinos, A.; Gorecki, D.C.; Zioupos, P.; Tong, J., Impact of P2RX7 ablation on the morphological, mechanical and tissue properties of bones in a murine model of duchenne muscular dystrophy. $J$ Biomech, 2016, 49, (14), 3444-3451.

[72] Kimmey, J.M.; Stallings, C.L., Bacterial Pathogens versus Autophagy: Implications for Therapeutic Interventions. Trends Mol Med, 2016, 22, (12), 1060-1076.

[73] Silva, B.J.; Barbosa, M.G.; Andrade, P.R.; Ferreira, H.; Nery, J.A.; Corte-Real, S.; da Silva, G.M.; Rosa, P.S.; Fabri, M.; Sarno, E.N.; Pinheiro, R.O., Autophagy Is an Innate Mechanism Associated with Leprosy Polarization. PLoS Pathog, 2017, 13, (1), e1006103.

[74] Biswas, D.; Qureshi, O.S.; Lee, W.Y.; Croudace, J.E.; Mura, M.; Lammas, D.A., ATP-induced autophagy is associated with rapid killing of intracellular mycobacteria within human monocytes/macrophages. BMC Immunol, 2008, 9, 35 . 

M.; Kojima, S.; Kitani, H.; Hashimoto, M., The activation of P2X7 receptor impairs lysosomal functions and stimulates the release of autophagolysosomes in microglial cells. J Immunol, 2009, 182, (4), 2051-2062.

[76] Yang, D.; He, Y.; Munoz-Planillo, R.; Liu, Q.; Nunez, G., Caspase-11 Requires the Pannexin-1 Channel and the Purinergic P2X7 Pore to Mediate Pyroptosis and Endotoxic Shock. Immunity, 2015, 43, (5), 923-932.

[77] Petrilli, V.; Papin, S.; Dostert, C.; Mayor, A.; Martinon, F.; Tschopp, J., Activation of the NALP3 inflammasome is triggered by low intracellular potassium concentration. Cell Death Differ, 2007, 14, (9), 1583-1589.

[78] Bergsbaken, T.; Fink, S.L.; Cookson, B.T., Pyroptosis: host cell death and inflammation. Nat Rev Microbiol, 2009, 7, (2), 99-109.

[79] Pizzirani, C.; Ferrari, D.; Chiozzi, P.; Adinolfi, E.; Sandona, D.; Savaglio, E.; Di Virgilio, F., Stimulation of P2 receptors causes release of IL-1beta-loaded microvesicles from human dendritic cells. Blood, 2007, 109, (9), 3856-3864.

[80] Gulinelli, S.; Salaro, E.; Vuerich, M.; Bozzato, D.; Pizzirani, C.; Bolognesi, G.; Idzko, M.; Di Virgilio, F.; Ferrari, D., IL-18 associates to microvesicles shed from human macrophages by a LPS/TLR-4 independent mechanism in response to P2X receptor stimulation. Eur J Immunol, 2012, 42, (12), 3334-3345.

[81] de Gassart, A.; Martinon, F., Pyroptosis: Caspase-11 Unlocks the Gates of Death. Immunity, 2015, 43, (5), 835837.

[82] Miao, E.A.; Rajan, J.V.; Aderem, A., Caspase-1-induced pyroptotic cell death. Immunol Rev, 2011, 243, (1), 206-214.

[83] Ferrari, D.; Pizzirani, C.; Adinolfi, E.; Lemoli, R.M.; Curti, A.; Idzko, M.; Panther, E.; Di Virgilio, F., The P2X7 receptor: a key player in IL-1 processing and release. J Immunol, 2006, 176, (7), 3877-3883.

[84] Piccini, A.; Carta, S.; Tassi, S.; Lasiglie, D.; Fossati, G.; Rubartelli, A., ATP is released by monocytes stimulated with pathogen-sensing receptor ligands and induces IL-1beta and IL-18 secretion in an autocrine way. Proc Natl Acad Sci U S A, 2008, 105, (23), 8067-8072.

[85] Di Virgilio, F., The therapeutic potential of modifying inflammasomes and NOD-like receptors. Pharmacol Rev, 2013, 65, (3), 872-905.

[86] Thornberry, N.A.; Bull, H.G.; Calaycay, J.R.; Chapman, K.T.; Howard, A.D.; Kostura, M.J.; Miller, D.K.; Molineaux, S.M.; Weidner, J.R.; Aunins, J.; et al., A novel heterodimeric cysteine protease is required for interleukin-1 beta processing in monocytes. Nature, 1992, 356, (6372), 768-774.

[87] Martinon, F.; Burns, K.; Tschopp, J., The inflammasome: a molecular platform triggering activation of inflammatory caspases and processing of proIL-beta. Mol Cell, 2002, 10, (2), 417-426.

[88] Ogura, Y.; Sutterwala, F.S.; Flavell, R.A., The inflammasome: first line of the immune response to cell stress. Cell, 2006, 126, (4), 659-662.

[89] Davis, B.K.; Wen, H.; Ting, J.P., The inflammasome NLRs in immunity, inflammation, and associated diseases. Annu Rev Immunol, 2011, 29, 707-735.

[90] El Kebir, D.; Jozsef, L.; Khreiss, T.; Filep, J.G., Inhibition of K+ efflux prevents mitochondrial dysfunction, and suppresses caspase-3-, apoptosis-inducing factor-, and endonuclease G-mediated constitutive apoptosis in human neutrophils. Cell Signal, 2006, 18, (12), 2302-2313.

[91] Englezou, P.C.; Rothwell, S.W.; Ainscough, J.S.; Brough, D.; Landsiedel, R.; Verkhratsky, A.; Kimber, I.; Dearman, R.J., P2X7R activation drives distinct IL-1 responses in dendritic cells compared to macrophages. Cytokine, 2015, 74, (2), 293-304. 
[92] Pizzirani, C.; Falzoni, S.; Govoni, M.; La Corte, R.; Donadei, S.; Di Virgilio, F.; Trotta, F.; Lo Monaco, A., Dysfunctional inflammasome in Schnitzler's syndrome. Rheumatology (Oxford), 2009, 48, (10), 1304-1308.

[93] Karmakar, M.; Katsnelson, M.A.; Dubyak, G.R.; Pearlman, E., Neutrophil P2X7 receptors mediate NLRP3 inflammasome-dependent IL-1beta secretion in response to ATP. Nat Commun, 2016, 7, 10555.

[94] Gustin, A.; Kirchmeyer, M.; Koncina, E.; Felten, P.; Losciuto, S.; Heurtaux, T.; Tardivel, A.; Heuschling, P.; Dostert, C., NLRP3 Inflammasome Is Expressed and Functional in Mouse Brain Microglia but Not in Astrocytes. PLoS One, 2015, 10, (6), e0130624.

[95] Minkiewicz, J.; de Rivero Vaccari, J.P.; Keane, R.W., Human astrocytes express a novel NLRP2 inflammasome. Glia, 2013, 61, (7), 1113-1121.

[96] Gicquel, T.; Robert, S.; Loyer, P.; Victoni, T.; Bodin, A.; Ribault, C.; Gleonnec, F.; Couillin, I.; Boichot, E.; Lagente, V., IL-1beta production is dependent on the activation of purinergic receptors and NLRP3 pathway in human macrophages. FASEB J, 2015, 29, (10), 4162-4173.

[97] Gross, O.; Thomas, C.J.; Guarda, G.; Tschopp, J., The inflammasome: an integrated view. Immunol Rev, 2011, $243,(1), 136-151$.

[98] Munoz-Planillo, R.; Kuffa, P.; Martinez-Colon, G.; Smith, B.L.; Rajendiran, T.M.; Nunez, G., K(+) efflux is the common trigger of NLRP3 inflammasome activation by bacterial toxins and particulate matter. Immunity, 2013, 38, (6), 1142-1153.

[99] He, Y.; Zeng, M.Y.; Yang, D.; Motro, B.; Nunez, G., NEK7 is an essential mediator of NLRP3 activation downstream of potassium efflux. Nature, 2016, 530, (7590), 354-357.

[100] Shi, H.; Wang, Y.; Li, X.; Zhan, X.; Tang, M.; Fina, M.; Su, L.; Pratt, D.; Bu, C.H.; Hildebrand, S.; Lyon, S.; Scott, L.; Quan, J.; Sun, Q.; Russell, J.; Arnett, S.; Jurek, P.; Chen, D.; Kravchenko, V.V.; Mathison, J.C.; Moresco, E.M.; Monson, N.L.; Ulevitch, R.J.; Beutler, B., NLRP3 activation and mitosis are mutually exclusive events coordinated by NEK7, a new inflammasome component. Nat Immunol, 2016, 17, (3), 250-258.

[101] Yaron, J.R.; Gangaraju, S.; Rao, M.Y.; Kong, X.; Zhang, L.; Su, F.; Tian, Y.; Glenn, H.L.; Meldrum, D.R., K(+) regulates $\mathrm{Ca}(2+)$ to drive inflammasome signaling: dynamic visualization of ion flux in live cells. Cell Death Dis, 2015 , $6, \mathrm{e} 1954$.

[102] Guerra, A.N.; Gavala, M.L.; Chung, H.S.; Bertics, P.J., Nucleotide receptor signalling and the generation of reactive oxygen species. Purinergic Signal, 2007, 3, (1-2), 39-51.

[103] Hewinson, J.; Moore, S.F.; Glover, C.; Watts, A.G.; MacKenzie, A.B., A key role for redox signaling in rapid P2X7 receptor-induced IL-1 beta processing in human monocytes. J Immunol, 2008, 180, (12), 8410-8420.

[104] Lenertz, L.Y.; Gavala, M.L.; Hill, L.M.; Bertics, P.J., Cell signaling via the P2X(7) nucleotide receptor: linkage to ROS production, gene transcription, and receptor trafficking. Purinergic Signal, 2009, 5, (2), 175-187.

[105] Liao, Y.H.; Lin, Y.C.; Tsao, S.T.; Lin, Y.C.; Yang, A.J.; Huang, C.T.; Huang, K.C.; Lin, W.W., HMG-CoA reductase inhibitors activate caspase-1 in human monocytes depending on ATP release and P2X7 activation. $J$ Leukoc Biol, 2013, 93, (2), 289-299.

[106] Hung, S.C.; Choi, C.H.; Said-Sadier, N.; Johnson, L.; Atanasova, K.R.; Sellami, H.; Yilmaz, O.; Ojcius, D.M., $\mathrm{P} 2 \mathrm{X} 4$ assembles with $\mathrm{P} 2 \mathrm{X} 7$ and pannexin-1 in gingival epithelial cells and modulates ATP-induced reactive oxygen species production and inflammasome activation. PLoS One, 2013, 8, (7), e70210.

[107] Kawano, A.; Tsukimoto, M.; Mori, D.; Noguchi, T.; Harada, H.; Takenouchi, T.; Kitani, H.; Kojima, S., Regulation of P2X7-dependent inflammatory functions by $\mathrm{P} 2 \mathrm{X} 4$ receptor in mouse macrophages. Biochem Biophys Res Commun, 2012, 420, (1), 102-107. 
[108] Rothmeier, A.S.; Marchese, P.; Petrich, B.G.; Furlan-Freguia, C.; Ginsberg, M.H.; Ruggeri, Z.M.; Ruf, W., Caspase-1-mediated pathway promotes generation of thromboinflammatory microparticles. J Clin Invest, 2015, 125, (4), 1471-1484.

[109] Franceschini, A.; Capece, M.; Chiozzi, P.; Falzoni, S.; Sanz, J.M.; Sarti, A.C.; Bonora, M.; Pinton, P.; Di Virgilio, F., The P2X7 receptor directly interacts with the NLRP3 inflammasome scaffold protein. FASEB J, 2015, 29, (6), 2450-2461.

[110] Salaro, E.; Rambaldi, A.; Falzoni, S.; Amoroso, F.S.; Franceschini, A.; Sarti, A.C.; Bonora, M.; Cavazzini, F.; Rigolin, G.M.; Ciccone, M.; Audrito, V.; Deaglio, S.; Pelegrin, P.; Pinton, P.; Cuneo, A.; Di Virgilio, F., Involvement of the P2X7-NLRP3 axis in leukemic cell proliferation and death. Sci Rep, 2016, 6, 26280.

[111] Tsai, C.Y.; Liong, K.H.; Gunalan, M.G.; Li, N.; Lim, D.S.; Fisher, D.A.; MacAry, P.A.; Leo, Y.S.; Wong, S.C.; Puan, K.J.; Wong, S.B., Type I IFNs and IL-18 regulate the antiviral response of primary human gammadelta T cells against dendritic cells infected with Dengue virus. J Immunol, 2015, 194, (8), 3890-3900.

[112] Mortimer, L.; Moreau, F.; Cornick, S.; Chadee, K., The NLRP3 Inflammasome Is a Pathogen Sensor for Invasive Entamoeba histolytica via Activation of alpha5beta1 Integrin at the Macrophage-Amebae Intercellular Junction. PLoS Pathog, 2015, 11, (5), e1004887.

[113] Csoka, B.; Nemeth, Z.H.; Toro, G.; Idzko, M.; Zech, A.; Koscso, B.; Spolarics, Z.; Antonioli, L.; Cseri, K.; Erdelyi, K.; Pacher, P.; Hasko, G., Extracellular ATP protects against sepsis through macrophage P2X7 purinergic receptors by enhancing intracellular bacterial killing. FASEB J, 2015, 29, (9), 3626-3637.

[114] Huang, S.W.; Walker, C.; Pennock, J.; Else, K.; Muller, W.; Daniels, M.J.; Pellegrini, C.; Brough, D.; LopezCastejon, G.; Cruickshank, S.M., P2X7 receptor-dependent tuning of gut epithelial responses to infection. Immunol Cell Biol, 2016.

[115] Iwata, M.; Ota, K.T.; Li, X.Y.; Sakaue, F.; Li, N.; Dutheil, S.; Banasr, M.; Duric, V.; Yamanashi, T.; Kaneko, K.; Rasmussen, K.; Glasebrook, A.; Koester, A.; Song, D.; Jones, K.A.; Zorn, S.; Smagin, G.; Duman, R.S., Psychological Stress Activates the Inflammasome via Release of Adenosine Triphosphate and Stimulation of the Purinergic Type $2 \mathrm{X} 7$ Receptor. Biol Psychiatry, 2016, 80, (1), 12-22.

[116] Xu, Y.; Sheng, H.; Bao, Q.; Wang, Y.; Lu, J.; Ni, X., NLRP3 inflammasome activation mediates estrogen deficiency-induced depression- and anxiety-like behavior and hippocampal inflammation in mice. Brain Behav Immun, 2016, 56, 175-186.

[117] Lappas, M., Caspase-1 activation is increased with human labour in foetal membranes and myometrium and mediates infection-induced interleukin-1beta secretion. Am J Reprod Immunol, 2014, 71, (2), 189-201.

[118] Maneta, E.; Warren, A.Y.; Hay, D.P.; Khan, R.N., Caspase-1-mediated cytokine release from gestational tissues, placental, and cord blood. Front Physiol, 2015, 6, 186.

[119] Maturana, C.J.; Aguirre, A.; Saez, J.C., High glucocorticoid levels during gestation activate the inflammasome in hippocampal oligodendrocytes of the offspring. Dev Neurobiol, 2016.

[120] Jimenez-Pacheco, A.; Diaz-Hernandez, M.; Arribas-Blazquez, M.; Sanz-Rodriguez, A.; Olivos-Ore, L.A.; Artalejo, A.R.; Alves, M.; Letavic, M.; Miras-Portugal, M.T.; Conroy, R.M.; Delanty, N.; Farrell, M.A.; O'Brien, D.F.; Bhattacharya, A.; Engel, T.; Henshall, D.C., Transient P2X7 Receptor Antagonism Produces Lasting Reductions in Spontaneous Seizures and Gliosis in Experimental Temporal Lobe Epilepsy. J Neurosci, 2016, 36, (22), $5920-5932$.

[121] Robert, S.; Gicquel, T.; Victoni, T.; Valenca, S.; Barreto, E.; Bailly-Maitre, B.; Boichot, E.; Lagente, V., Involvement of matrix metalloproteinases (MMPs) and inflammasome pathway in molecular mechanisms of fibrosis. Biosci Rep, 2016, 36, (4). 
[122] Zhang, Q.; Yu, W.; Lee, S.; Xu, Q.; Naji, A.; Le, A.D., Bisphosphonate Induces Osteonecrosis of the Jaw in Diabetic Mice via NLRP3/Caspase-1-Dependent IL-1beta Mechanism. J Bone Miner Res, 2015, 30, (12), $2300-2312$.

[123] Vivoli, E.; Cappon, A.; Milani, S.; Piombanti, B.; Provenzano, A.; Novo, E.; Masi, A.; Navari, N.; Narducci, R.; Mannaioni, G.; Moneti, G.; Oliveira, C.P.; Parola, M.; Marra, F., NLRP3 inflammasome as a target of berberine in experimental murine liver injury: interference with P2X7 signalling. Clin Sci (Lond), 2016, 130, (20), 1793-1806.

[124] Zhao, J.; Wang, H.; Dai, C.; Wang, H.; Zhang, H.; Huang, Y.; Wang, S.; Gaskin, F.; Yang, N.; Fu, S.M., P2X7 blockade attenuates murine lupus nephritis by inhibiting activation of the NLRP3/ASC/caspase 1 pathway. Arthritis Rheum, 2013, 65, (12), 3176-3185.

[125] Zhang, Y.; Yuan, F.; Cao, X.; Zhai, Z.; GangHuang; Du, X.; Wang, Y.; Zhang, J.; Huang, Y.; Zhao, J.; Hou, W., P2X7 receptor blockade protects against cisplatin-induced nephrotoxicity in mice by decreasing the activities of inflammasome components, oxidative stress and caspase-3. Toxicol Appl Pharmacol, 2014, 281, (1), 1-10.

[126] Feng, L.; Chen, Y.; Ding, R.; Fu, Z.; Yang, S.; Deng, X.; Zeng, J., P2X7R blockade prevents NLRP3 inflammasome activation and brain injury in a rat model of intracerebral hemorrhage: involvement of peroxynitrite. $J$ Neuroinflammation, 2015, 12, 190.

[127] Ghosh, S.; Karin, M., Missing pieces in the NF-kappaB puzzle. Cell, 2002, 109 Suppl, S81-96.

[128] Hayden, M.S.; Ghosh, S., Signaling to NF-kappaB. Genes Dev, 2004, 18, (18), 2195-2224.

[129] Mitchell, S.; Vargas, J.; Hoffmann, A., Signaling via the NFkappaB system. Wiley Interdiscip Rev Syst Biol Med, 2016, 8, (3), 227-241.

[130] Hatada, E.N.; Nieters, A.; Wulczyn, F.G.; Naumann, M.; Meyer, R.; Nucifora, G.; McKeithan, T.W.; Scheidereit, C., The ankyrin repeat domains of the NF-kappa B precursor p105 and the protooncogene bcl-3 act as specific inhibitors of NF-kappa B DNA binding. Proc Natl Acad Sci U S A, 1992, 89, (6), 2489-2493.

[131] Karin, M.; Ben-Neriah, Y., Phosphorylation meets ubiquitination: the control of NF-[kappa]B activity. Annu Rev Immunol, 2000, 18, 621-663.

[132] Hayden, M.S.; Ghosh, S., Shared principles in NF-kappaB signaling. Cell, 2008, 132, (3), 344-362.

[133] Baltimore, D., NF-kappaB is 25. Nat Immunol, 2011, 12, (8), 683-685.

[134] Ferrari, D.; Wesselborg, S.; Bauer, M.K.; Schulze-Osthoff, K., Extracellular ATP activates transcription factor NF-kappaB through the P2Z purinoreceptor by selectively targeting NF-kappaB p65. J Cell Biol, 1997, 139, (7), 16351643.

[135] Korcok, J.; Raimundo, L.N.; Ke, H.Z.; Sims, S.M.; Dixon, S.J., Extracellular nucleotides act through P2X7 receptors to activate NF-kappaB in osteoclasts. J Bone Miner Res, 2004, 19, (4), 642-651.

[136] Genetos, D.C.; Karin, N.J.; Geist, D.J.; Donahue, H.J.; Duncan, R.L., Purinergic signaling is required for fluid shear stress-induced NF-kappaB translocation in osteoblasts. Exp Cell Res, 2011, 317, (6), 737-744.

[137] Liu, Y.; Xiao, Y.; Li, Z., P2X7 receptor positively regulates MyD88-dependent NF-kappaB activation. Cytokine, 2011, 55, (2), 229-236.

[138] Marques, C.C.; Castelo-Branco, M.T.; Pacheco, R.G.; Buongusto, F.; do Rosario, A., Jr.; Schanaider, A.; Coutinho-Silva, R.; de Souza, H.S., Prophylactic systemic P2X7 receptor blockade prevents experimental colitis. Biochim Biophys Acta, 2014, 1842, (1), 65-78.

[139] Huang, C.; Yu, W.; Cui, H.; Wang, Y.; Zhang, L.; Han, F.; Huang, T., P2X7 blockade attenuates mouse liver fibrosis. Mol Med Rep, 2014, 9, (1), 57-62. 
[140] Moncao-Ribeiro, L.C.; Faffe, D.S.; Santana, P.T.; Vieira, F.S.; da Graca, C.L.; Marques-da-Silva, C.; Machado, M.N.; Caruso-Neves, C.; Zin, W.A.; Borojevic, R.; Takiya, C.M.; Coutinho-Silva, R., P2X7 receptor modulates inflammatory and functional pulmonary changes induced by silica. PLoS One, 2014, 9, (10), e110185.

[141] Zanin, R.F.; Bergamin, L.S.; Morrone, F.B.; Coutinho-Silva, R.; de Souza Wyse, A.T.; Battastini, A.M., Pathological concentrations of homocysteine increases IL-1beta production in macrophages in a P2X7, NF-kB, and erkdependent manner. Purinergic Signal, 2015, 11, (4), 463-470.

[142] Chang, X.; He, H.; Zhu, L.; Gao, J.; Wei, T.; Ma, Z.; Yan, T., Protective effect of apigenin on Freund's complete adjuvant-induced arthritis in rats via inhibiting P2X7/NF-kappaB pathway. Chem Biol Interact, 2015, 236, 41-46.

[143] Zhang, K.; Liu, J.; You, X.; Kong, P.; Song, Y.; Cao, L.; Yang, S.; Wang, W.; Fu, Q.; Ma, Z., P2X7 as a new target for chrysophanol to treat lipopolysaccharide-induced depression in mice. Neurosci Lett, 2016, 613, 60-65.

[144] Tafani, M.; Schito, L.; Pellegrini, L.; Villanova, L.; Marfe, G.; Anwar, T.; Rosa, R.; Indelicato, M.; Fini, M.; Pucci, B.; Russo, M.A., Hypoxia-increased RAGE and P2X7R expression regulates tumor cell invasion through phosphorylation of Erk1/2 and Akt and nuclear translocation of NF-\{kappa $\}$ B. Carcinogenesis, 2011, 32, (8), 1167-1175.

[145] Baricordi, O.R.; Ferrari, D.; Melchiorri, L.; Chiozzi, P.; Hanau, S.; Chiari, E.; Rubini, M.; Di Virgilio, F., An ATP-activated channel is involved in mitogenic stimulation of human T lymphocytes. Blood, 1996, 87, (2), $682-690$.

[146] Vergani, A.; Tezza, S.; D'Addio, F.; Fotino, C.; Liu, K.; Niewczas, M.; Bassi, R.; Molano, R.D.; Kleffel, S.; Petrelli, A.; Soleti, A.; Ammirati, E.; Frigerio, M.; Visner, G.; Grassi, F.; Ferrero, M.E.; Corradi, D.; Abdi, R.; Ricordi, C.; Sayegh, M.H.; Pileggi, A.; Fiorina, P., Long-term heart transplant survival by targeting the ionotropic purinergic receptor P2X7. Circulation, 2013, 127, (4), 463-475.

[147] Vergani, A.; Fotino, C.; D'Addio, F.; Tezza, S.; Podetta, M.; Gatti, F.; Chin, M.; Bassi, R.; Molano, R.D.; Corradi, D.; Gatti, R.; Ferrero, M.E.; Secchi, A.; Grassi, F.; Ricordi, C.; Sayegh, M.H.; Maffi, P.; Pileggi, A.; Fiorina, P., Effect of the purinergic inhibitor oxidized ATP in a model of islet allograft rejection. Diabetes, 2013, 62, (5), 1665-1675. [148] Yu, T.; Junger, W.G.; Yuan, C.; Jin, A.; Zhao, Y.; Zheng, X.; Zeng, Y.; Liu, J., Shockwaves increase T-cell proliferation and IL-2 expression through ATP release, P2X7 receptors, and FAK activation. Am J Physiol Cell Physiol, 2010, 298, (3), C457-464

[149] Yip, L.; Woehrle, T.; Corriden, R.; Hirsh, M.; Chen, Y.; Inoue, Y.; Ferrari, V.; Insel, P.A.; Junger, W.G., Autocrine regulation of T-cell activation by ATP release and P2X7 receptors. FASEB J, 2009, 23, (6), 1685-1693.

[150] Adinolfi, E.; Callegari, M.G.; Cirillo, M.; Pinton, P.; Giorgi, C.; Cavagna, D.; Rizzuto, R.; Di Virgilio, F., Expression of the $\mathrm{P} 2 \mathrm{X} 7$ receptor increases the $\mathrm{Ca} 2+$ content of the endoplasmic reticulum, activates NFATc1, and protects from apoptosis. J Biol Chem, 2009, 284, (15), 10120-10128.

[151] Grol, M.W.; Pereverzev, A.; Sims, S.M.; Dixon, S.J., P2 receptor networks regulate signaling duration over a wide dynamic range of ATP concentrations. J Cell Sci, 2013, 126, (Pt 16), 3615-3626.

[152] Adinolfi, E.; Amoroso, F.; Giuliani, A.L., P2X7 Receptor Function in Bone-Related Cancer. J Osteoporos, 2012, 2012,637863 .

[153] Kataoka, A.; Tozaki-Saitoh, H.; Koga, Y.; Tsuda, M.; Inoue, K., Activation of P2X7 receptors induces CCL3 production in microglial cells through transcription factor NFAT. J Neurochem, 2009, 108, (1), 115-125.

[154] Kim, E.A.; Cho, C.H.; Kim, J.; Hahn, H.G.; Choi, S.Y.; Yang, S.J.; Cho, S.W., The azetidine derivative, KHG26792 protects against ATP-induced activation of NFAT and MAPK pathways through P2X7 receptor in microglia. Neurotoxicology, 2015, 51, 198-206.

[155] Shiratori, M.; Tozaki-Saitoh, H.; Yoshitake, M.; Tsuda, M.; Inoue, K., P2X7 receptor activation induces CXCL2 production in microglia through NFAT and PKC/MAPK pathways. J Neurochem, 2010, 114, (3), 810-819. 
[156] Pippel, A.; Bessler, B.; Klapperstuck, M.; Markwardt, F., Inhibition of antigen receptor-dependent Ca(2+) signals and NF-AT activation by P2X7 receptors in human B lymphocytes. Cell Calcium, 2015, 57, (4), $275-289$.

[157] Hill, L.M.; Gavala, M.L.; Lenertz, L.Y.; Bertics, P.J., Extracellular ATP may contribute to tissue repair by rapidly stimulating purinergic receptor X7-dependent vascular endothelial growth factor release from primary human monocytes. J Immunol, 2010, 185, (5), 3028-3034.

[158] Tung, H.C.; Lee, F.Y.; Wang, S.S.; Tsai, M.H.; Lee, J.Y.; Huo, T.I.; Huang, H.C.; Chuang, C.L.; Lin, H.C.; Lee, S.D., The Beneficial Effects of P2X7 Antagonism in Rats with Bile Duct Ligation-induced Cirrhosis. PLoS One, 2015, 10, (5), e0124654.

[159] Mizutani, T.; Fowler, B.J.; Kim, Y.; Yasuma, R.; Krueger, L.A.; Gelfand, B.D.; Ambati, J., Nucleoside Reverse Transcriptase Inhibitors Suppress Laser-Induced Choroidal Neovascularization in Mice. Invest Ophthalmol Vis Sci, 2015, $56,(12), 7122-7129$.

[160] Tafani, M.; De Santis, E.; Coppola, L.; Perrone, G.A.; Carnevale, I.; Russo, A.; Pucci, B.; Carpi, A.; Bizzarri, M.; Russo, M.A., Bridging hypoxia, inflammation and estrogen receptors in thyroid cancer progression. Biomed Pharmacother, 2014, 68, (1), 1-5.

[161] Amoroso, F.; Falzoni, S.; Adinolfi, E.; Ferrari, D.; Di Virgilio, F., The P2X7 receptor is a key modulator of aerobic glycolysis. Cell Death Dis, 2012, 3, e370.

[162] Wei, W.; Ryu, J.K.; Choi, H.B.; McLarnon, J.G., Expression and function of the P2X(7) receptor in rat C6 glioma cells. Cancer Lett, 2008, 260, (1-2), 79-87.

[163] Chong, J.H.; Zheng, G.G.; Ma, Y.Y.; Zhang, H.Y.; Nie, K.; Lin, Y.M.; Wu, K.F., The hyposensitive N187D P2X7 mutant promotes malignant progression in nude mice. J Biol Chem, 2010, 285, (46), 36179-36187.

[164] Solini, A.; Simeon, V.; Derosa, L.; Orlandi, P.; Rossi, C.; Fontana, A.; Galli, L.; Di Desidero, T.; Fioravanti, A.; Lucchesi, S.; Coltelli, L.; Ginocchi, L.; Allegrini, G.; Danesi, R.; Falcone, A.; Bocci, G., Genetic interaction of P2X7 receptor and VEGFR-2 polymorphisms identifies a favorable prognostic profile in prostate cancer patients. Oncotarget, 2015, 6, (30), 28743-28754.

[165] Di Virgilio, F.; Falzoni, S.; Giuliani, A.L.; Adinolfi, E., P2 receptors in cancer progression and metastatic spreading. Curr Opin Pharmacol, 2016, 29, 17-25.

[166] Baricordi, O.R.; Melchiorri, L.; Adinolfi, E.; Falzoni, S.; Chiozzi, P.; Buell, G.; Di Virgilio, F., Increased proliferation rate of lymphoid cells transfected with the P2X(7) ATP receptor. J Biol Chem, 1999, 274, (47), 3320633208 .

[167] Adinolfi, E.; Melchiorri, L.; Falzoni, S.; Chiozzi, P.; Morelli, A.; Tieghi, A.; Cuneo, A.; Castoldi, G.; Di Virgilio, F.; Baricordi, O.R., P2X7 receptor expression in evolutive and indolent forms of chronic B lymphocytic leukemia. Blood, 2002, 99, (2), 706-708.

[168] Kaidanovich-Beilin, O.; Woodgett, J.R., GSK-3: Functional Insights from Cell Biology and Animal Models. Front Mol Neurosci, 2011, 4, 40.

[169] Fruman, D.A.; Rommel, C., PI3K and cancer: lessons, challenges and opportunities. Nat Rev Drug Discov, 2014, $13,(2), 140-156$.

[170] Hogarty, M.D.; Maris, J.M., PI3King on MYCN to improve neuroblastoma therapeutics. Cancer Cell, 2012, 21, (2), 145-147.

[171] Gomez-Villafuertes, R.; Garcia-Huerta, P.; Diaz-Hernandez, J.I.; Miras-Portugal, M.T., PI3K/Akt signaling pathway triggers P2X7 receptor expression as a pro-survival factor of neuroblastoma cells under limiting growth conditions. Sci Rep, 2015, 5, 18417. 
[172] Qiu, Y.; Li, W.H.; Zhang, H.Q.; Liu, Y.; Tian, X.X.; Fang, W.G., P2X7 mediates ATP-driven invasiveness in prostate cancer cells. PLoS One, 2014, 9, (12), e114371.

[173] Paredes, J.; Figueiredo, J.; Albergaria, A.; Oliveira, P.; Carvalho, J.; Ribeiro, A.S.; Caldeira, J.; Costa, A.M.; Simoes-Correia, J.; Oliveira, M.J.; Pinheiro, H.; Pinho, S.S.; Mateus, R.; Reis, C.A.; Leite, M.; Fernandes, M.S.; Schmitt, F.; Carneiro, F.; Figueiredo, C.; Oliveira, C.; Seruca, R., Epithelial E- and P-cadherins: role and clinical significance in cancer. Biochim Biophys Acta, 2012, 1826, (2), 297-311.

[174] Xia, J.; Yu, X.; Tang, L.; Li, G.; He, T., P2X7 receptor stimulates breast cancer cell invasion and migration via the AKT pathway. Oncol Rep, 2015, 34, (1), 103-110.

[175] Koene, R.J.; Prizment, A.E.; Blaes, A.; Konety, S.H., Shared Risk Factors in Cardiovascular Disease and Cancer. Circulation, 2016, 133, (11), 1104-1114.

[176] Miraglia, E.; Hogberg, J.; Stenius, U., Statins exhibit anticancer effects through modifications of the pAkt signaling pathway. Int J Oncol, 2012, 40, (3), 867-875.

[177] Mistafa, O.; Hogberg, J.; Stenius, U., Statins and ATP regulate nuclear pAkt via the P2X7 purinergic receptor in epithelial cells. Biochem Biophys Res Commun, 2008, 365, (1), 131-136.

[178] Mistafa, O.; Stenius, U., Statins inhibit Akt/PKB signaling via P2X7 receptor in pancreatic cancer cells. Biochem Pharmacol, 2009, 78, (9), 1115-1126.

[179] Mistafa, O.; Ghalali, A.; Kadekar, S.; Hogberg, J.; Stenius, U., Purinergic receptor-mediated rapid depletion of nuclear phosphorylated Akt depends on pleckstrin homology domain leucine-rich repeat phosphatase, calcineurin, protein phosphatase 2A, and PTEN phosphatases. J Biol Chem, 2010, 285, (36), 27900-27910.

[180] Jacques-Silva, M.C.; Rodnight, R.; Lenz, G.; Liao, Z.; Kong, Q.; Tran, M.; Kang, Y.; Gonzalez, F.A.; Weisman, G.A.; Neary, J.T., P2X7 receptors stimulate AKT phosphorylation in astrocytes. Br J Pharmacol, 2004, 141, (7), 11061117.

[181] Grol, M.W.; Zelner, I.; Dixon, S.J., P2X(7)-mediated calcium influx triggers a sustained, PI3K-dependent increase in metabolic acid production by osteoblast-like cells. Am J Physiol Endocrinol Metab, 2012, 302, (5), E561-575.

[182] Neary, J.T.; Kang, Y., P2 purinergic receptors signal to glycogen synthase kinase-3beta in astrocytes. J Neurosci Res, 2006, 84, (3), 515-524.

[183] Neary, J.T.; Zimmermann, H., Trophic functions of nucleotides in the central nervous system. Trends Neurosci, 2009, 32, (4), 189-198. 


\section{Apoptosis}

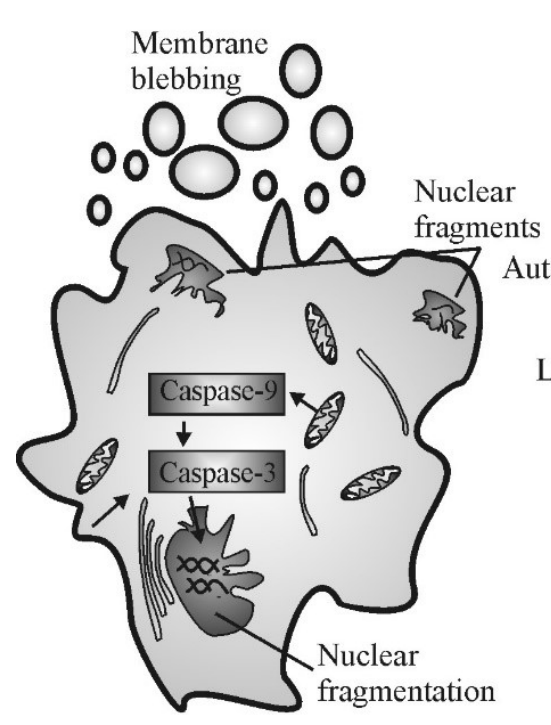

- Mitochondrial potential collapse

- Mitochondrial fragmentation

- ROS production

- Apoptotic caspase activation

- Cell blebbing

- Cell shrinkage

- Nuclear fragmentation

- Chromatin condensation

Autophagy

\section{Pyroptosis}

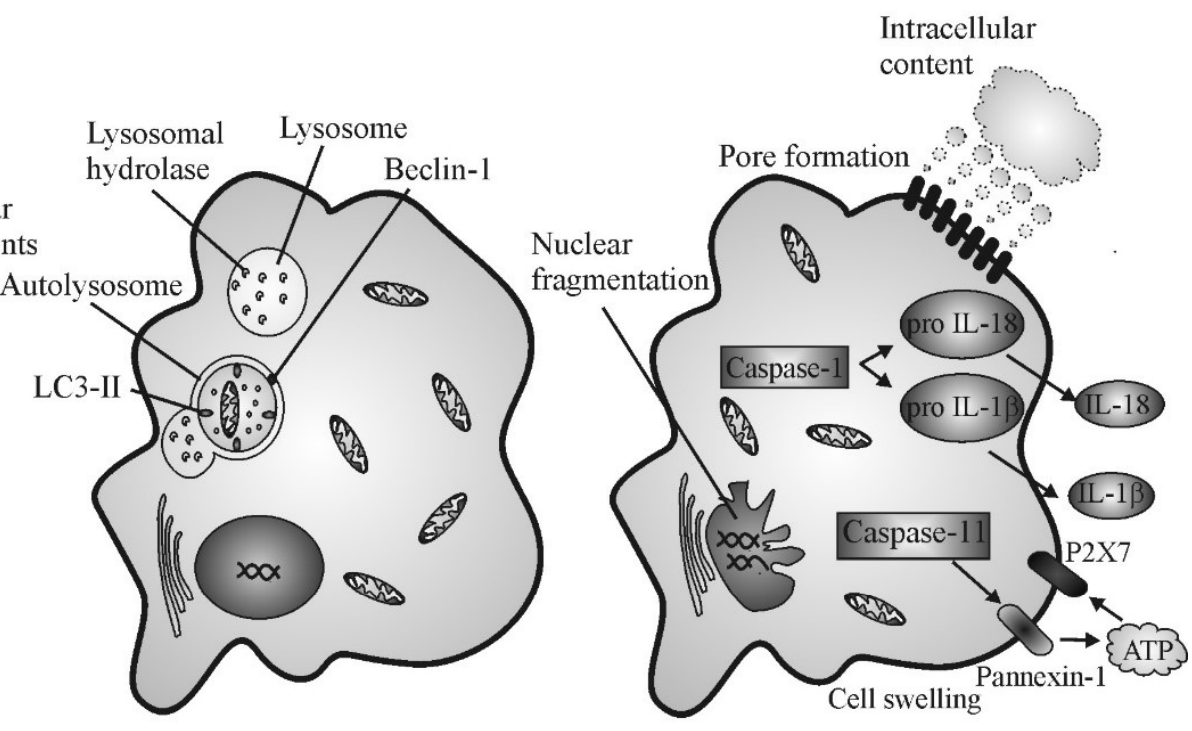

- Beclin-1 activation

- LC3-II overexpressiom

- Lysosomal alkalinisation

- Interaction of P2X7-dependent

large pore and HSP90
- Caspase-1 activation

- Caspase-11 activation

- IL-1 $\beta$ release

- Pannexin-1 cleavage

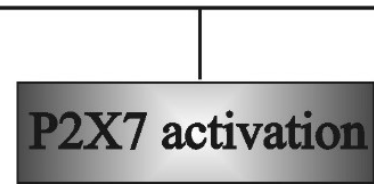

Figure 1. Signalling cascades activated by P2X7 during cell death and autophagy. P2X7 can initiate apoptosis by causing a robust $\mathrm{Ca}^{2+}$ increase leading to cell blebbing and shrinkage, caspases cleavage, mitochondrial fragmentation and potential collapse, ROS production and inactivation of the nuclear function. P2X7 plays a role also in the autophagic process where it up-modulates autophagosome formation via beclin-1 and LC3-II. In the immune cell specific form of cell death pyroptosis, P2X7 causes maturation and secretion of pro-inflammatory cytokines via activation of caspase-1. Caspase -11 , by cleaving pannexin-1 cause release of ATP leading to P2X7 activation. 


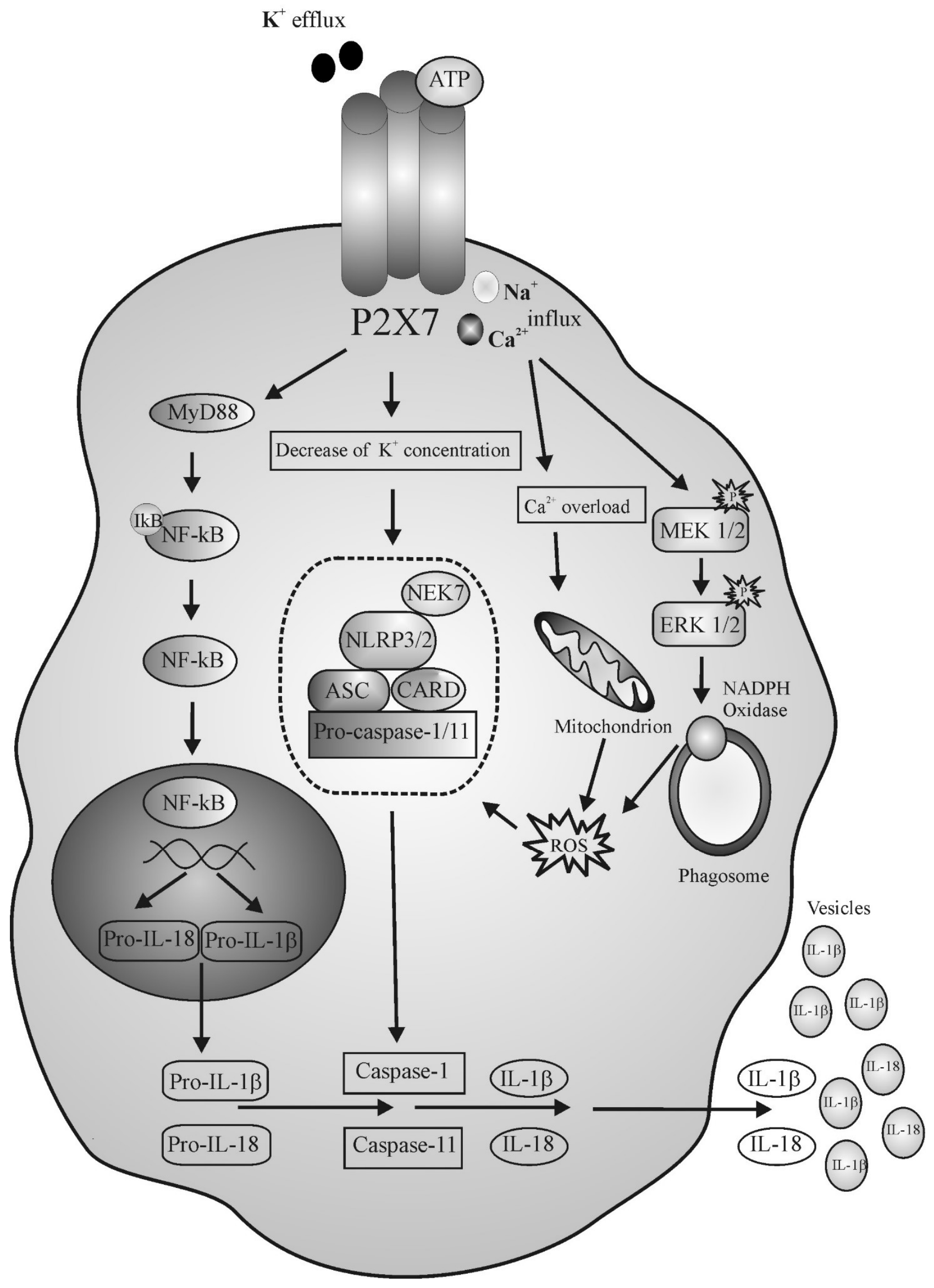


Figure 2. P2X7 -dependent inflammatory pathways. The $\mathrm{P} 2 \mathrm{X} 7$ receptor plays an important role in the maturation and secretion of IL-1 $\beta$ by a direct interaction with the components of different inflammasomes including NLRP2, NLRP3 and ASC. The inflammasome converts pro-caspases- 1 and -11 into mature caspases- 1 and -11 that, in turn, cleave pro-IL- $1 \beta$ and pro-IL-18 to generate the active cytokines. P2X7 activates vesicular release of these mature cytokines. The $\mathrm{K}^{+}$ concentration decrease is the most common mechanism of inflammasome activation. NEK7 kinase can sense the ATPactivated $\mathrm{K}^{+}$decrease and bind to NLRP3 regulating its function. P2X7 triggers ROS production via mitochondrial $\mathrm{Ca}^{2+}$ overload or NADPH assembly, leading to inflammasome activation. Furthermore, P2X7, through interaction with MyD88, causes NF-kB activation. 


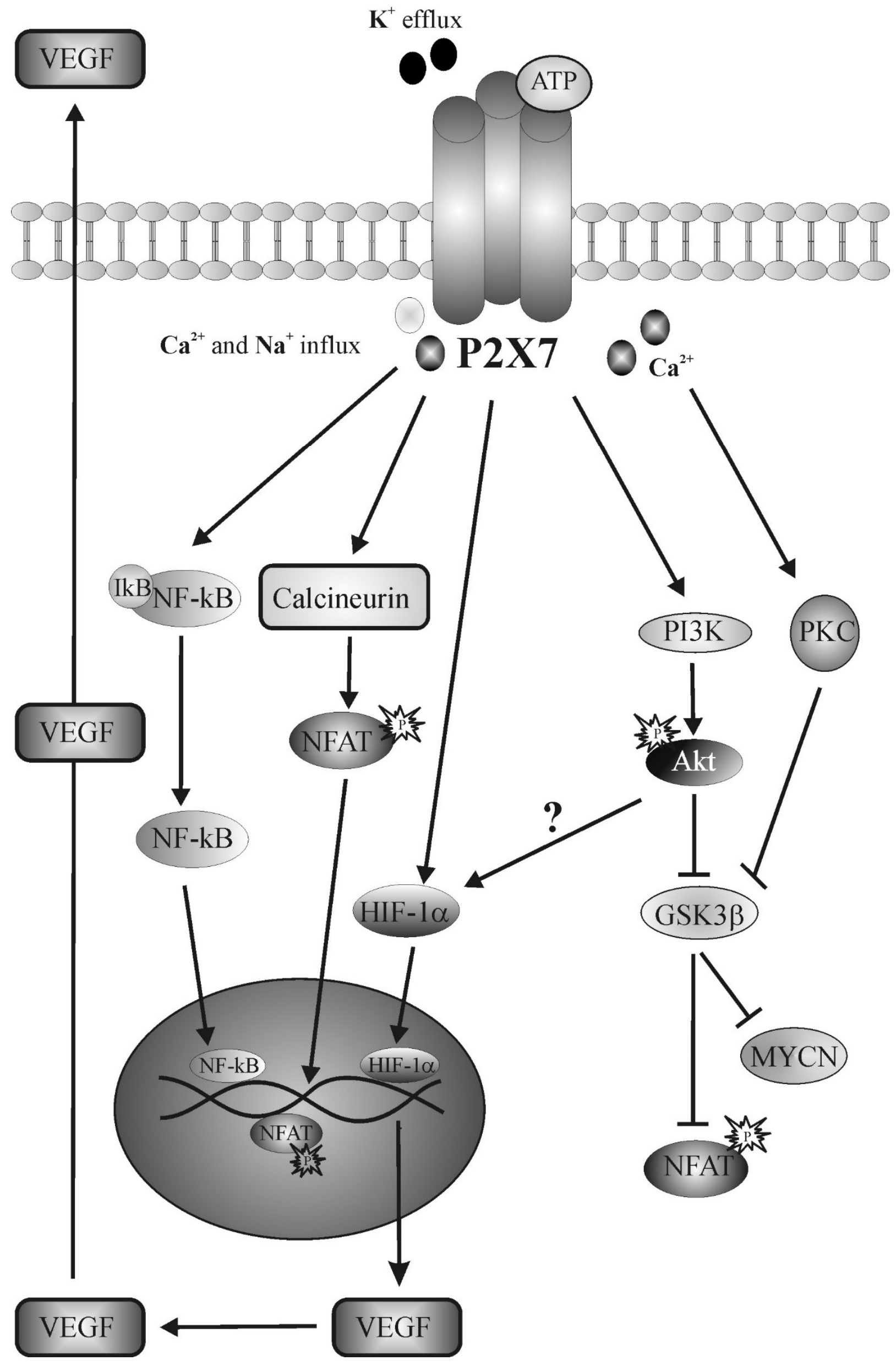


Figure 3. P2X7 activated oncogenic pathways. P2X7 triggers activation of different nuclear factors associated to oncogenesis. P2X7-dependent. $\mathrm{Ca}^{2+}$ influx activates calcineurin causing NFAT phosphorylation and its nuclear migration. P2X7 triggers PI3K/Akt metabolic pathway activation, driving HIF-1 $\alpha$ into the nucleus, thus stimulating VEGF production and release leading to tumoral vascularization. P2X7 inhibits GSK3 $\beta$, which, consequently, cannot direct MYCN to proteasomal degradation and negatively regulate NFAT nuclear translocation. 